\title{
Some non-genetic factors affecting commercial pig production in Zimbabwe
}

\author{
F. Mungate \\ Department of Animal Science, University of Zimbabwe, P.O. Box MP 167, Mt. Pleasant, \\ Harare, Zimbabwe \\ K. Dzama* \\ Department of Paraclinical Veterinary Studies, University of Zimbabwe, P.O. Box MP 167, \\ Mt. Pleasant, Harare, Zimbabwe \\ K. Mandisodza and A. Shoniwa \\ Pig Industry Board, P.O. Box HG297, Highlands, Harare, Zimbabwe
}

Received April 1998; accepted August 1999

\begin{abstract}
The effect of environmental factors on preweaning performance traits was studied using 3556 records collected between 1980 and 1995. Sow performance in terms of number born alive was higher if sows farrowed in summer months of October to April than at any other time of the year $(P<0.05)$. The heaviest piglets were also born during the same period $(P<0.05)$ even though they did not maintain the weight advantage through to 21 days and to weaning age at 35 days $(P<0.05)$. Sows in parity seven and beyond had smaller litters, with lower birth weights and growth rates to weaning $(P<0.05)$ thus justifying the practise of culling sows after the sixth parity. Crossbred sows generally outperformed pure-bred sows for litter size because they exhibit maternal heterosis. Hampshire sired litters were significantly larger than those sired by other sire breeds $(P<0.05)$. Furthermore Hampshire and Duroc sired piglets generally performed better than both the Landrace and Large White sired litters. Discrimination of coloured breeds carcasses means that producers in Zimbabwe cannot take advantage of their superiority.
\end{abstract}

Keywords: non-genetic factors, pigs, Zimbabwe

*To whom correspondence should be addressed.

\section{Introduction}

The growing competitiveness within the pig industry demands that the scale and efficiency of production of weaner pigs for fattening to slaughter weights be increased (Holness \& Chabeuf, 1991). As a result, pig producers aim to improve the management of the preweaning and post-weaning stages of production to the limits dictated by the genetics of the animals. The ultimate aim is to produce numerically more weaner pigs with carcass qualities that are dictated by the market. The main factors that interact in the determination of the quantity and quality of the final pig carcass are the genetics and environment of the animal, and the interaction between the two. Some pigs tend to have a genetic constitution that is superior to others and non-genetic factors can mask this advantage. In selecting pigs which are most likely to transmit their desirable genes to the next generation, attempts are made to consider both the genetics and environment and to balance them. Some important non-genetic factors include parity of the sow, month of farrowing and weaning, year of farrowing and general management which includes nutrition and health. 
In Zimbabwe commercial pig production is based on exotic breeds like the Landrace and Large White breeds. Even though pig production is carried out indoors, the productivity of imported temperate breeds is affected by the tropical environment. It is important to quantify non-genetic or tropical environmental effects on imported temperate pig breeds. Earlier efforts by Pathiraja et al. (1990) and Maburutse (1992) to study the effect of non-genetic factors in the Zimbabwean pig industry were of limited scope, less comprehensive and with very small data sets.

The objectives of this study were to determine the effects of non-genetic factors on litter size at birth, piglet birth weight, 21-day weight and weaning weight, and preweaning daily weight gain of commercial pigs reared at the Pig Industry Board Research (PIB) Farm at Arcturus in Zimbabwe.

\section{Materials and methods}

The field data were from pigs which were part of the commercial herd at the PIB experimental farm which is located in Arcturus, thirty kilometres east of Harare in an intensive mixed crop (maize, wheat and soyabeans) farming area. The farm is involved in demonstration and extension of pig production techniques in Zimbabwe. The altitude is approximately 1500 meters above sea level. Mean temperatures during the warm humid summer (October-March) average $21^{\circ} \mathrm{C}$ while the cool dry winter averages $16^{\circ} \mathrm{C}$. The mean annual rainfall is $800 \mathrm{~mm}$.

\section{General management}

Breeding females were observed for oestrus and those in standing heat were served. All matings were natural. All sows were mated three times using the same boar at 12 hour intervals after standing heat. Pregnancy diagnosis was carried out 28 days after mating and sows returning to oestrus were served again. Sows failing to conceive after the second oestrus were culled. Sows were brought to the farrowing crates seven days before parturition. Immediately after farrowing the umbilical cord of each piglet was cut and iodine applied. Litter sizes and farrowing mortalities were recorded after which piglets were ear-notched for identification. Pedigree information and sex of each piglet were recorded. Piglets were individually weighed and had their teeth clipped. Piglets in litter sizes in excess of twelve were fostered randomly to other sows.

All piglets had access to moistened red soil as a source of iron. In addition, creep feed and clean water were supplied ad libitum from day seven until weaning. The piglets were individually weighed at 21 and 35 days of age after which they were weaned. Mortalities between birth and weaning were recorded. From the crop of piglets, those to be used for replacement were fed $4 \mathrm{~kg}$ of sow meal per animal per day until they were mated and older sows were fed $5 \mathrm{~kg}$ of sow meal per animal from weaning to mating. All breeding females were given $2 \mathrm{~kg}$ of the meal per day until farrowing. The composition of the diets fed to the pigs is shown in Table 1. Gilts were vaccinated against sterility, mummification of piglets, embryo death and infertility (SMEDI) two to three weeks before mating and sows were vaccinated only in the event of an outbreak of a disease. The Large White (L), Landrace (R) and Large White-Landrace (LR), Hampshire-Landrace (HR), Large White-Large White-Landrace (LLR) and Landrace-Landrace-Large White (LRR) crosses were used as dam lines and Duroc (D), Hampshire (H), Large White (L) and Landrace (R) were used as sire lines. Boars used at the farm were locally bred or bought in from other pig breeders.

\section{Data preparation}

A total of 3875 litters' records which were collected between 1980 and 1995 were used in this study. These pigs were from one herd. Litter size records outside the range 5-15 piglets were pooled and similarly weaned litter size outside the range 5-12 piglets and parities beyond 10 . Sow 


\begin{tabular}{lccc}
\hline \multicolumn{4}{l}{ Table 1 Composition (\%) of the diets fed to pigs } \\
\hline & Creep & Grower-finisher & Sow and boar \\
\hline Maize meal & 64.5 & 73.2 & 74.4 \\
Soyabean meal & 31.0 & 23.0 & 21.0 \\
Monocalcium Phosphate & 2.0 & 1.3 & 2.3 \\
Limestone Flour & 1.5 & 1.5 & 1.3 \\
Vitamin Mineral Premix & 1.0 & 1.0 & 1.0 \\
\hline
\end{tabular}

breeds with less than 100 records and sires with less than 5 litters were also deleted. In total $8.2 \%$ of the data was lost and 3556 litters were finally available for statistical analysis.

\section{Statistical analysis}

Data was analyzed using the Generalized Linear Models (SAS, 1994). The traits studied were number born alive (BALIVE), average birth weight (AVGBWT), average 21-day piglet weight and pre 21-day daily weight gain (THRAVGWT and THRADG), piglet weaning weight and preweaning average daily weight gain (AVGWWT and ADGWEAN). The independent variables considered were breed of sow and sire, month and year of farrowing, parity of the sow and the relevant covariates. The final models used were:

\section{Model 1: number born alive}

$$
Y_{i j k l m n}=\mu+P_{i}+M_{j}+T_{k}+S_{1}+D_{m}+b_{1}(\text { AVGBWT })_{i j k l m n}+E_{i j k l m n}
$$

where $Y_{\mathrm{ijklmn}}$ was the number of piglets born alive in the $\mathrm{n}^{\text {th }}$ litter, born to a sow of the $\mathrm{i}^{\text {th }}$ parity and $\mathrm{m}^{\text {th }}$ breed, which farrowed in the $\mathrm{j}^{\text {th }}$ month and $\mathrm{k}^{\text {th }}$ year and mated to the $\mathrm{l}^{\text {th }}$ sire breed; $\mu$ was the overall mean litter size and AVGBWT was average birth weight as a covariate. It was assumed that the trait number born alive was normally distributed due to large number of observations and was analysed thus.

\section{Model 2: average birth weight}

Average birth weight was analysed using the same model as Model 1 but average birth weight (AVGBWT) was removed as a covariate and replaced by number born alive (BALIVE).

Model 3: pre-21-day average daily weight gain and preweaning average daily weight gain These traits were analysed using the same model as Model 2.

Model 4: average 21-doy weight

This trait was analysed using an extension of Model 1 with both number born alive (BALIVE) and average birth weight (AVGBWT) as covariates.

\section{Model 5: average weaning weight}

Average weaning weight was analysed using an extension of Model 4 with an additional covariate WEANAGE (age of the piglet at weaning). 


\section{Results and discussion}

Table 2 shows the number of observations, raw means and standard deviations of the traits studied. Table 3 shows a summary of results of the analysis of variance (ANOVA). In the preliminary analyses no two factor interactions were significant $(P>0.05)$ and were removed from the models. Birth weight, parity, sow and sire breed, month and year of birth were significant sources of variation for number born alive $(P<0.01)$. Number born alive, parity, breed of the sow and the boar, farrowing month and year all significantly affected average birth weight $(P<0.01)$. Average daily weight gain up to 21 days was significantly affected by number of pigs born alive, parity, sow breed, farrowing year $(P<0.01)$, sire breed and month of farrowing $(P<0.05)$. Average weight at 21 days was significantly affected by average birth weight, number born alive, parity, sow breed, farrowing month and year $(P<0.01)$ and sire breed $(P<0.05)$. Preweaning average daily weight gain was significantly affected by number born alive, parity, farrowing year $(\mathrm{P}<0.01)$, sow breed and farrowing month $(P<0.05)$. Average weaning weight was significantly affected by average birth weight, number born alive, parity, farrowing month and year, age at weaning $(P<0.01)$ and sow and sire breed $(P<0.05)$. Tables $4 \mathrm{a}$ and $4 \mathrm{~b}$ show the least squares means for the effect of parity of sow on all the traits studied. Tables $5 \mathrm{a}$ and $5 \mathrm{~b}$ show the least squares means for the effect of season of farrowing on all the traits studied. Tables 6 and 7 show the least squares means for the effect of breed of sow and breed of sire respectively on the traits studied.

\section{Effect of number born alive on average birth weight}

It is well documented that as litter size increases, the average birth weight of the piglets decreases. More piglets per litter imply an increased competition for nutrients in-utero which will then lead to a decline in the average birth weight of the piglets. According to English et al. (1988), with larger litter sizes, average birth weight of piglets declines, variation in piglet birth weight increases and the incidence of such problems as clumsiness and agalactia also increases.

Table 2 Number of observations, raw means and their standard deviations for the traits number born alive (BALIVE), average birth weight (AVGBWT), average weight at 21 days (THRAVGWT), average weaning weight (AVGWWT), average daily gain to 21 days (THRADG) and average dail gain to weaning (ADGWEAN)

\begin{tabular}{lccc}
\hline Trait & $\mathrm{n}$ & Mean & SD \\
\hline BALIVE & 3515 & 10.16 & 2.521 \\
AVGBWT $(\mathrm{kg})$ & 3515 & 1.44 & 0.227 \\
THRAVGWT $(\mathrm{kg})$ & 3344 & 5.09 & 0.750 \\
AVGWWT $(\mathrm{kg})$ & 3340 & 8.02 & 1.209 \\
THRADG $(\mathrm{kg})$ & 3344 & 0.17 & 0.036 \\
ADGWEAN $(\mathrm{kg})$ & 3092 & 2.00 & 0.437 \\
\hline
\end{tabular}


Table 3 Summary of the $F$ statistics for number of piglets born alive (BALIVE), average birth weight (AVGBWT), average 21-day weight (THRAVGWT), average weaning weight (AVGWWT), pre-21-day average daily weight gain (THRADG) and preweaning average daily weight gain (ADGWEAN)

\begin{tabular}{lccccccc}
\hline Item & df & BALIVE & AVGBWT & THRAVGWT & AVGWWT & THRADG & ADGWEAN \\
\hline AVGBWT & 1 & $415.00^{* *}$ & - & $158.37^{* *}$ & $123.37^{* *}$ & - & - \\
BALIVE & 1 & - & $415.00^{* *}$ & $101.69^{* *}$ & $124.27^{* *}$ & $101.69^{* *}$ & $171.86^{* *}$ \\
Parity & 9 & $24.92^{* *}$ & $13.63^{* *}$ & $7.97^{* *}$ & $5.42^{* *}$ & $7.97^{* *}$ & $8.81^{* *}$ \\
SOWBRD & 5 & $5.23^{* *}$ & $7.05^{* *}$ & $3.74^{* *}$ & $2.47^{*}$ & $3.74^{* *}$ & $2.61^{*}$ \\
SIREBRD & 3 & $8.05^{* *}$ & $27.73^{* *}$ & $2.80^{*}$ & $2.64^{*}$ & $2.80^{*}$ & 1.11 \\
FMONTH & 11 & $2.89^{* *}$ & $3.69^{* *}$ & $9.28^{* *}$ & $3.84^{* *}$ & $9.28^{*}$ & $5.75^{*}$ \\
FYEAR & 12 & $7.59^{* *}$ & $37.74^{* *}$ & $11.30^{* *}$ & $29.73^{* *}$ & $11.30^{* *}$ & $27.74^{* *}$ \\
WEANAGE & 1 & - & - & - & $1559.42^{* *}$ & - & - \\
\hline *P $<0.05 ; * \mathrm{P}<0.01$ & & & & & & \\
\hline
\end{tabular}

Table 4a Least squares means for the effect of parity on number of piglets born alive (BALIVE), average birth weight (AVGBWT) and 21-day average weight (THRAVGWT)

\begin{tabular}{lccccc}
\hline Parity & N & BALIVE & AVGBWT (kg) & $\mathrm{n}$ & THRAVGWT (kg) \\
\hline 1 & 603 & $9.02^{\mathrm{a}} \pm 0.14$ & $1.45^{\mathrm{a}} \pm 0.01$ & 555 & $5.08^{\mathrm{a}} \pm 0.04$ \\
2 & 547 & $9.66^{\mathrm{a}} \pm 0.14$ & $1.57^{\mathrm{b}} \pm 0.01$ & 522 & $5.26^{\mathrm{b}} \pm 0.04$ \\
3 & 498 & $10.27^{\mathrm{b}} \pm 0.15$ & $1.54^{\mathrm{b}, \mathrm{c}} \pm 0.01$ & 479 & $5.15^{\mathrm{b}} \pm 0.04$ \\
4 & 462 & $10.81^{\mathrm{c}} \pm 0.15$ & $1.53^{\mathrm{c}} \pm 0.01$ & 449 & $5.17^{\mathrm{b}} \pm 0.05$ \\
5 & 377 & $10.84^{\mathrm{c}} \pm 0.16$ & $1.50^{\mathrm{c}, \mathrm{d}} \pm 0.01$ & 363 & $5.08^{\mathrm{a}} \pm 0.05$ \\
6 & 339 & $10.79^{\mathrm{c}} \pm 0.17$ & $1.50^{\mathrm{c}, \mathrm{d}} \pm 0.02$ & 329 & $5.06^{\mathrm{a}} \pm 0.05$ \\
7 & 295 & $10.55^{\mathrm{b}, \mathrm{c}} \pm 0.17$ & $1.47^{\mathrm{a}, \mathrm{d}} \pm 0.02$ & 275 & $4.98^{\mathrm{a}} \pm 0.05$ \\
8 & 196 & $10.54^{\mathrm{b}, \mathrm{c}} \pm 0.20$ & $1.45^{\mathrm{a}} \pm 0.02$ & 187 & $4.88^{\mathrm{a}, \mathrm{c}} \pm 0.07$ \\
9 & 137 & $10.33^{\mathrm{b}} \pm 0.24$ & $1.44^{\mathrm{a}} \pm 0.02$ & 130 & $4.86^{\mathrm{a}, \mathrm{c}} \pm 0.07$ \\
10 & 102 & $10.19^{\mathrm{b}} \pm 0.27$ & $1.47^{\mathrm{a}, \mathrm{d}} \pm 0.02$ & 97 & $4.87^{\mathrm{a}, \mathrm{c}} \pm 0.08$ \\
\hline
\end{tabular}

Means in the same column with different superscripts differ significantly $(\mathrm{P}<0.05)$ 
Table $\mathbf{4 b}$ Least squares means for the effect of parity on average weaning weight (AVGWWT), pre-21day average daily weight gain (THRADG) and preweaning average daily weight gain (ADGWEAN)

\begin{tabular}{lcccccc}
\hline Parity & $\mathrm{n}$ & AVGWWT $(\mathrm{kg})$ & $\mathrm{n}$ & THRADG $(\mathrm{kg})$ & $\mathrm{n}$ & ADGWEAN (kg) \\
\hline 1 & 555 & $7.86^{\mathrm{a}} \pm 0.07$ & 555 & $0.169^{\mathrm{b}, \mathrm{c}} \pm 0.002$ & 517 & $0.196^{\mathrm{c}} \pm 0.004$ \\
2 & 522 & $8.16^{\mathrm{b}, \mathrm{c}} \pm 0.07$ & 522 & $0.183^{\mathrm{a}} \pm 0.002$ & 478 & $0.214^{\mathrm{a}} \pm 0.004$ \\
3 & 478 & $8.12^{\mathrm{b}, \mathrm{c}} \pm 0.07$ & 479 & $0.177^{\mathrm{b}} \pm 0.002$ & 452 & $0.214^{\mathrm{a}} \pm 0.004$ \\
4 & 448 & $8.25^{\mathrm{b}, \mathrm{c}} \pm 0.07$ & 449 & $0.178^{\mathrm{b}, \mathrm{c}} \pm 0.002$ & 417 & $0.213^{\mathrm{a}} \pm 0.004$ \\
5 & 364 & $8.09^{\mathrm{b}} \pm 0.08$ & 363 & $0.173^{\mathrm{b}, \mathrm{c}} \pm 0.002$ & 341 & $0.206^{\mathrm{b}} \pm 0.00$ \\
6 & 329 & $8.00^{\mathrm{b}} \pm 0.08$ & 329 & $0.172^{\mathrm{c}} \pm 0.002$ & 307 & $0.200^{\mathrm{b}, \mathrm{c}} \pm 0.005$ \\
7 & 274 & $8.03^{\mathrm{b}} \pm 0.09$ & 275 & $0.169^{\mathrm{c}} \pm 0.003$ & 255 & $0.206^{\mathrm{b}} \pm 0.005$ \\
8 & 187 & $7.75^{\mathrm{a}} \pm 0.10$ & 187 & $0.164^{\mathrm{c}} \pm 0.003$ & 173 & $0.197^{\mathrm{c}} \pm 0.005$ \\
9 & 130 & $7.84^{\mathrm{a}} \pm 0.12$ & 130 & $0.163^{\mathrm{c}} \pm 0.003$ & 110 & $0.201^{\mathrm{b}, \mathrm{c}} \pm 0.006$ \\
10 & 97 & $7.83^{\mathrm{a}} \pm 0.13$ & 97 & $0.163^{\mathrm{c}} \pm 0.004$ & 84 & $0.200^{\mathrm{b}, \mathrm{c}} \pm 0.006$ \\
\hline
\end{tabular}

Means in the same column with different superscripts differ significantly $(P<0.05)$

Table 5a Least squares means for the effect of farrowing month on number of piglets born alive (BALIVE), average birth weight (AVGBWT) and average 21-day weight (THRAVGWT)

\begin{tabular}{lcccccc}
\hline Farrowing month & $\mathrm{n}$ & BALIVE & $\mathrm{n}$ & AVGBWT (kg) & $\mathrm{n}$ & THRAVGWT (kg) \\
\hline Jan & 258 & $10.66^{\mathrm{a}} \pm 0.18$ & 258 & $1.50^{\mathrm{a}, \mathrm{c}} \pm 0.02$ & 247 & $4.84^{\mathrm{c}} \pm 0.06$ \\
Feb & 243 & $10.56^{\mathrm{a}} \pm 0.19$ & 243 & $1.51^{\mathrm{a}, \mathrm{c}} \pm 0.02$ & 232 & $4.83^{\mathrm{c}} \pm 0.06$ \\
Mar & 267 & $10.43^{\mathrm{a}} \pm 0.18$ & 267 & $1.49^{\mathrm{a}, \mathrm{c}} \pm 0.02$ & 260 & $4.90^{\mathrm{b}, \mathrm{c}} \pm 0.06$ \\
Apr & 285 & $10.23^{\mathrm{b}} \pm 0.18$ & 285 & $1.48^{\mathrm{a}} \pm 0.02$ & 275 & $4.96^{\mathrm{b}} \pm 0.05$ \\
May & 329 & $10.03^{\mathrm{b}, \mathrm{c}} \pm 0.17$ & 329 & $1.45^{\mathrm{b}} \pm 0.02$ & 311 & $5.04^{\mathrm{b}} \pm 0.05$ \\
Jun & 301 & $9.75^{\mathrm{c}} \pm 0.18$ & 301 & $1.49^{\mathrm{a}, \mathrm{c}} \pm 0.02$ & 277 & $5.12^{\mathrm{a}} \pm 0.06$ \\
Jul & 285 & $10.10^{\mathrm{b}, \mathrm{c}} \pm 0.18$ & 285 & $1.46^{\mathrm{b}} \pm 0.02$ & 272 & $5.19^{\mathrm{a}} \pm 0.05$ \\
Aug & 365 & $10.23^{\mathrm{b}} \pm 0.16$ & 365 & $1.46^{\mathrm{b}} \pm 0.02$ & 351 & $5.23^{\mathrm{a}} \pm 0.05$ \\
Sep & 347 & $10.54^{\mathrm{a}} \pm 0.16$ & 347 & $1.50^{\mathrm{a}, \mathrm{c}} \pm 0.02$ & 331 & $5.14^{\mathrm{a}} \pm 0.05$ \\
Oct & 310 & $10.30^{\mathrm{b}} \pm 0.17$ & 310 & $1.49^{\mathrm{a}, \mathrm{c}} \pm 0.02$ & 297 & $5.18^{\mathrm{a}} \pm 0.05$ \\
Nov & 277 & $10.29^{\mathrm{b}} \pm 0.18$ & 289 & $1.54^{\mathrm{a}, \mathrm{c}} \pm 0.02$ & 275 & $5.06^{\mathrm{b}} \pm 0.06$ \\
Dec & 289 & $10.50^{\mathrm{a}} \pm 0.18$ & 289 & $1.52^{\mathrm{a}, \mathrm{c}} \pm 0.02$ & 275 & $4.94^{\mathrm{b}, \mathrm{c}} \pm 0.05$ \\
\hline
\end{tabular}

Means in the same column with different superscripts differ significantly $(P<0.05)$ 
Table 5b Least squares means for the effect of farrowing month on average weaning weight (AVGWWT), pre-21-day average daily weight gain (THRADG) and average pre-weaning daily weight gain (ADGWEAN)

\begin{tabular}{lcccccc}
\hline Month & $\mathrm{n}$ & AVGWWT $(\mathrm{kg})$ & $\mathrm{n}$ & THRADG $(\mathrm{kg})$ & $\mathrm{n}$ & ADGWEAN $(\mathrm{kg})$ \\
\hline Jan & 247 & $8.12^{\mathrm{a}} \pm 0.09$ & 247 & $0.162^{\mathrm{c}} \pm 0.003$ & 229 & $0.214^{\mathrm{a}} \pm 0.005$ \\
Feb & 232 & $8.00^{\mathrm{a}} \pm 0.09$ & 232 & $0.162^{\mathrm{c}} \pm 0.003$ & 207 & $0.208^{\mathrm{a}} \pm 0.005$ \\
Mar & 260 & $7.80^{\mathrm{b}} \pm 0.09$ & 260 & $0.165^{\mathrm{c}} \pm 0.003$ & 231 & $0.203^{\mathrm{a}, \mathrm{b}} \pm 0.005$ \\
Apr & 275 & $7.79^{\mathrm{b}} \pm 0.09$ & 275 & $0.168^{\mathrm{c}} \pm 0.003$ & 246 & $0.193^{\mathrm{c}} \pm 0.005$ \\
May & 310 & $8.02^{\mathrm{a}} \pm 0.09$ & 311 & $0.171^{\mathrm{b}, \mathrm{c}} \pm 0.003$ & 293 & $0.204^{\mathrm{b}} \pm 0.005$ \\
Jun & 278 & $7.96^{\mathrm{a}} \pm 0.09$ & 277 & $0.175^{\mathrm{b}} \pm 0.003$ & 260 & $0.193^{\mathrm{c}} \pm 0.005$ \\
Jul & 272 & $8.12^{\mathrm{a}} \pm 0.09$ & 272 & $0.179^{\mathrm{a}, \mathrm{b}} \pm 0.003$ & 259 & $0.204^{\mathrm{a}, \mathrm{b}} \pm 0.005$ \\
Aug & 349 & $8.19^{\mathrm{a}} \pm 0.08$ & 351 & $0.181^{\mathrm{a}} \pm 0.002$ & 336 & $0.206^{\mathrm{a}} \pm 0.005$ \\
Sep & 331 & $8.16^{\mathrm{a}} \pm 0.08$ & 331 & $0.176^{\mathrm{a}, \mathrm{b}} \pm 0.003$ & 321 & $0.214^{\mathrm{a}} \pm 0.005$ \\
Oct & 297 & $7.99^{\mathrm{a}} \pm 0.08$ & 297 & $0.178^{\mathrm{a}, \mathrm{b}} \pm 0.003$ & 271 & $0.209^{\mathrm{a}} \pm 0.005$ \\
Nov & 258 & $7.96^{\mathrm{a}} \pm 0.09$ & 258 & $0.173^{\mathrm{b}, \mathrm{c}} \pm 0.003$ & 233 & $0.204^{\mathrm{a}, \mathrm{b}} \pm 0.005$ \\
Dec & 275 & $7.81^{\mathrm{b}} \pm 0.09$ & 275 & $0.167^{\mathrm{c}} \pm 0.003$ & 248 & $0.202^{\mathrm{a}, \mathrm{b}} \pm 0.005$ \\
\hline
\end{tabular}

Means in the same column with different superscripts differ significantly $(P<0.05)$

Table 6 Least squares means for sow breed effect on number of piglets born alive (BALIVE), average birth weight (AVGBWT), 21-day average weight (THRAVGWT), average weaning weight (AVGWWT), pre-21-day average daily weight gain (THRADG) and pre-weaning average daily weight gain (ADGWEAN)

\begin{tabular}{lccccccccc}
\hline $\begin{array}{l}\text { Sow } \\
\text { breed }\end{array}$ & $n$ & BALIVE & $\begin{array}{c}\text { AVGBWT } \\
(\mathrm{kg})\end{array}$ & $\mathrm{n}$ & $\begin{array}{c}\text { THRAVGWT } \\
(\mathrm{kg})\end{array}$ & $\begin{array}{c}\text { THRADG } \\
(\mathrm{kg})\end{array}$ & $\begin{array}{c}\text { AVGWW } \\
\mathrm{n}(\mathrm{kg})\end{array}$ & $\begin{array}{c}\text { ADGWEA } \\
\mathrm{N}(\mathrm{kg})\end{array}$ \\
\hline $\mathrm{HR}$ & 188 & $10.40^{\mathrm{a}} \pm 0.23$ & $1.55^{\mathrm{a}} \pm 0.02$ & 174 & $5.16^{\mathrm{a}} \pm 0.07$ & $0.18^{\mathrm{a}} \pm 0.003$ & 173 & $8.24^{\mathrm{a}, \mathrm{c}} \pm 0.11$ & $0.204^{\mathrm{a}} \pm 0.005$ \\
$\mathrm{~L}$ & 161 & $10.49^{\mathrm{a}} \pm 0.23$ & $1.44^{\mathrm{b}, \mathrm{c}} \pm 0.02$ & 157 & $4.90^{\mathrm{c}} \pm 0.07$ & $0.165^{\mathrm{b}} \pm 0.003$ & 157 & $7.84^{\mathrm{b}, \mathrm{c}} \pm 0.11$ & $0.202^{\mathrm{a}} \pm 0.005$ \\
LLR & 310 & $10.29^{\mathrm{a}} \pm 0.16$ & $1.46^{\mathrm{b}} \pm 0.02$ & 294 & $4.94^{\mathrm{c}} \pm 0.05$ & $0.167^{\mathrm{b}} \pm 0.002$ & 295 & $7.86^{\mathrm{b}, \mathrm{c}} \pm 0.08$ & $0.203^{\mathrm{a}} \pm 0.005$ \\
LR & 1908 & $10.53^{\mathrm{a}} \pm 0.09$ & $1.48^{\mathrm{b}} \pm 0.01$ & 1829 & $5.05^{\mathrm{b}} \pm 0.03$ & $0.17^{\mathrm{c}} \pm 0.001$ & 1827 & $7.95^{\mathrm{b}, \mathrm{c}} \pm 0.04$ & $0.205^{\mathrm{a}} \pm 0.004$ \\
LRR & 167 & $10.08^{\mathrm{a}, \mathrm{b}} \pm 0.21$ & $1.48^{\mathrm{b}} \pm 0.02$ & 166 & $5.16^{\mathrm{a}} \pm 0.06$ & $0.18^{\mathrm{a}} \pm 0.003$ & 166 & $8.09^{\mathrm{a}, \mathrm{c}} \pm 0.10$ & $0.213^{\mathrm{b}} \pm 0.005$ \\
$\mathrm{R}$ & 822 & $10.01^{\mathrm{b}} \pm 0.12$ & $1.52^{\mathrm{a}} \pm 0.010$ & 766 & $5.02^{\mathrm{b}} \pm 0.04$ & $0.17^{\mathrm{c}} \pm 0.002$ & 766 & $7.98^{\mathrm{b}, \mathrm{c}} \pm 0.06$ & $0.200^{\mathrm{a}} \pm 0.004$ \\
\hline
\end{tabular}

Means in the same column with different superscripts differ significantly $(\mathrm{P}<0.05)$

$\mathrm{HR}=$ Hampshire $\times$ Landrace; $\mathrm{L}=$ Large White; LLR $=$ Large White $\times$ Large White $\times$ Landrace LR $=$ Large White $\times$ Landrace; LRR $=$ Large White $\times$ Landrace $\times$ Landrace; $R=$ Landrace 
Table 7 Least squares means for sire breed effect on number of piglets born alive (BALIVE), average birth weight (AVGBWT), average 21-day weight (THRAVGWT), average weaning weight (AVGWWT), average daily weight gain up to 21 days (THRADG)

\begin{tabular}{|c|c|c|c|c|c|c|c|c|}
\hline $\begin{array}{l}\text { Sire } \\
\text { breed }\end{array}$ & $\mathrm{n}$ & BALIVE & $\begin{array}{c}\text { AVGBWT } \\
(\mathrm{kg})\end{array}$ & $\mathrm{n}$ & $\begin{array}{c}\text { THRAVGWT } \\
(\mathrm{kg})\end{array}$ & $\begin{array}{l}\text { THRADG } \\
(\mathrm{kg})\end{array}$ & $n$ & $\begin{array}{c}\text { AVGWWT } \\
(\mathrm{kg})\end{array}$ \\
\hline D & 190 & $9.77^{\mathrm{a}} \pm 0.21$ & $1.49^{\mathrm{a}} \pm 0.02$ & 177 & $5.08^{a} \pm 0.06$ & $0.174^{a} \pm 0.003$ & 178 & $8.07^{a} \pm 0.10$ \\
\hline $\mathrm{H}$ & 145 & $11.15^{b} \pm 0.24$ & $1.62^{\mathrm{b}} \pm 0.02$ & 131 & $5.15^{b} \pm 0.08$ & $0.176^{\mathrm{a}} \pm 0.004$ & 131 & $8.13^{a} \pm 0.12$ \\
\hline $\mathrm{L}$ & 2117 & $10.19^{c} \pm 0.09$ & $1.43^{c} \pm 0.01$ & 2026 & $4.96^{\mathrm{c}} \pm 0.03$ & $0.168^{\mathrm{b}} \pm 0.001$ & 2023 & $7.91^{a} \pm 0.04$ \\
\hline $\mathrm{R}$ & 1104 & $10.10^{c} \pm 0.10$ & $1.43^{c} \pm 0.01$ & 1052 & $4.96^{c} \pm 0.031$ & $0.168^{\mathrm{b}} \pm 0.001$ & 1052 & $7.85^{b} \pm 0.05$ \\
\hline
\end{tabular}

Means in the same column with different superscripts differ significantly $(P<0.05)$

$\mathrm{D}=$ Duroc $; \mathrm{H}=$ Hampshire $\mathrm{L}=$ Large White; $\mathrm{R}=$ Landrace

Effect of average birth weight on weight gains to 21 days, average weight at 21 days, preweaning daily weight gains and weight at weaning

Heavier farrowed piglets had significantly higher average daily weight gain up to 21 days, up to weaning, average 21 day weights and weaning weight $(P<0.01)$. This is expected since piglet birth weight is genetically highly correlated to other subsequent weight traits. Piglets of higher birth weights consume more milk per suckle than their lighter litter mates and this could be the major reason why heavier piglets outgain lighter ones (Campbell \& Dunkin, 1982).

\section{Effect of parity on number born alive}

Litters born to sows in their early $(1-3)$ and late ( 7 and beyond) parities were smaller $(\mathrm{P}<0.05)$ compared to those born to sows in their mid-parities (4-6). This is probably because gilts and young sows produce fewer fertile ova compared to mature sows (MacPherson et al., 1977). Older sows tend to have a higher incidence of farrowing problems like dystocia, which lead to higher piglet mortalities. This has been attributed to the reduced muscle tone which sets in as the sows grow older, resulting in farrowing problems (English et al., 1988). In addition English et al. (1988) concluded that the incidence of stillbirths increases after the sixth parity.

\section{Effect of parity on average birth weight}

The average birth weight of the piglets peaked in sows in parities 2 and 3 before declining thereafter $(P<0.05)$. Parities 8 through 10 have the smallest birth weights $(P<0.05)$. Gilts have low birth weights because they are still physiologically immature and hence have to partition nutrients between their own growth requirements and those of the foetuses. Furthermore the uterine capacity tends to limit the birth weights of piglets farrowed by gilts. On the other hand old sows tend to undergo a physiological deterioration and hence may not utilise their feed resources most efficiently in providing nutrition to the foetuses in utero.

Effect of parity on the weight traits

Except for parity 2, piglets in smaller litters (parities 1 and 7 and beyond) did not gain weight to 21 
days of age faster than those bom in bigger litters as would be expected. This is probably because gilts and old sows have poorer milk production capabilities. The same general trend is maintained for all the other weight traits studied confirming the high positive genetic and phenotypic correlations among these traits.

Commercial pig producers in Zimbabwe routinely cull sows after the sixth parity. Results from this study seem to justify this practice. The consequence of this practice may be to push sows into producing better in earlier than later parities.

\section{Effect of season on number born alive}

As shown in Table 5a, litters farrowed in early summer (September) to late summer (April) were significantly larger $(\mathrm{P}<0.05)$ than those farrowed in the winter months (May to August). However, the month in which the sows were mated had no effect on litter size $(P>0.05)$. The highest litter sizes were obtained in those piglets farrowed in January and the lowest in June. However, Brooks (1991) reported that under hot summer conditions, pregnant or lactating sows eat less, lose more weight and this tends to lower birth weights and litter sizes in summer. In addition boars are thought to be less fertile under hot summer conditions. Prior to this study there was a general belief that the same situation prevails in Zimbabwe. The findings of this study would seem to suggest that farmers should improve their breeding management in the winter instead. The possible negative effect of high ambient summer temperatures may be ameliorated if the pigs are kept in well designed pens which provide a lot of shade. The effect of food supply is not a factor since the pigs were fed indoors under relatively similar conditions throughout the year.

\section{Effect of season on average birth weight}

The heaviest piglets were farrowed from September up to March and the lightest were farrowed in May $(P<0.05)$. The same trend was observed for litter size. This was unexpected since number born alive was also highest in the same period and the two factors are supposed to be inversely related. Summer farrowed litters do not seem to maintain their superiority to weaning. Winter farrowed piglets seemed to catch-up and outgain their summer farrowed counterparts in terms of average daily gain at 21 days of age and at weaning. Brooks (1991) postulated that there is an increased rate of mobilization of body reserves by sows in summer due to a decrease in appetite induced by the high temperatures. This results in increased growth during prenatal life by $15 \%$ but a decrease in growth rate by $12 \%$ after birth.

\section{Effect of breed of sow on number born alive}

All crossbred sows except the LRR farrowed larger litter sizes than the pure-bred Landrace sows (P $<0.05$ ) but not the Large White sows. Crossbred sows generally outperformed pure-bred sows for litter size because they exhibit maternal heterosis. The popularity of Landrace sows $(n=1908)$ and Large White $\times$ Landrace sows $(n=822)$ would therefore not be justified by litter size.

\section{Effect of breed of sow on the weight traits}

The crossbred sow Hampshire $\times$ Landrace (HR) and the pure-bred Landrace farrowed the heaviest piglets $(P<0.05)$. In addition the HR and the LRR farrowed piglets had the highest average daily gains at 21 days $(P<0.05)$ while the Landrace and $L R$ farrowed piglets ranked second. However this advantage in average daily gains had disappeared at weaning. Superiority in average daily gains at 21 days of age can be attributed to the sow's ability to produce milk. The performance of HR sows seems not to be matched by their popularity both in this study ( $=188$ ) and in 
commercial pig production throughout Zimbabwe. The unpopularity of the breed derives from the fact that slaughterhouses and meat packing plants down-grade carcasses from coloured breeds.

\section{Effect of sire breed}

Even though the Large White was the most popular sire breed $(n=2117)$ being used almost twice as many times as the Landrace, there was no significant difference in their performance in all traits studied. Hampshire sired litters were significantly larger than those sired by other sire breeds $(\mathrm{P}<$ 0.05). In addition Hampshire and Duroc sired piglets generally performed better than both the Landrace and Large White sired litters even though the former sire breeds were used sparingly. Hampshire and Duroc sires are generally used as terminal sires. Discrimination of coloured breeds carcasses means that producers in Zimbabwe won't be able to take advantage of their superiority.

\section{Acknowledgements}

Support from the Pig Industry Board and the University of Zimbabwe Research Board is gratefully acknowledged. Dr Jestina Kusina read the manual and made some very useful comments.

\section{References}

BROOKS, P., 1991. Summer infertility: rain helps play. Pig Farming 39, 48.

CAMPBELL, R.G., \& DUNKIN, A.C., 1982. Effect of birth weight on the estimated milk intake, growth and body composition of sow reared pigs. Animal Production 35, 193.

FNGLISH, P.R., SMITH, W.J. \& MCLEAN, A.., 1988. The sow: improving her efficiency. Farming Press Ltd. Suffolk, United Kingdom.

HOLNESS, D.H. \& CHABEUF, N., 1991. Pigs. McMillan Education Limited, London, UK.

MABURUTSE, Z.A., 1992. Crossbreeding for weaner pig production in Zimbabwe. MSc Thesis, University of Zimbabwe. Harare, Zimbabwe.

MACPHERSON, R.M., HOVEL.L, F.D. \& JONES, A.S., 1977. Performance of sows first mated at puberty or second or third oestrus, and carcass assessment of once-bred gilts. Animal Production 24, 333.

SAS., 1994. SAS User's Guide: Statistics. SAS Institute. Inc. Cary, NC. 